\title{
Nutrient Composition and Sensory Evaluation of Complementary Food Made From Maize, Plantain Soybean Blends
}

\author{
Noah Abimbola Aduke* \\ Department of Food Technology, The Federal Polytechnic, Ilaro, Nigeria \\ *Corresponding author
}

\section{A B S T R A C T}

Complementary foods were formulated from maize, plantain and Soybean composite blends in different ratios100\% Maize as the control; 65:15:20, 60:10:30, 70:15:15, maize plantain soybean respectively. The Nutrient and sensory qualities of the composite formulations were evaluated. The ash content ranged from $1.00 \pm 0.00$ to $3.05 \pm 0.08 \%$

\section{Keywords}

Nutrient, maize, plantain, soya bean, complementary food

Article Info

\section{Accepted:}

28 October 2017

Available Online:

10 December 2017 with the crude protein ranging from $10.60 \pm 0.05$ to $15.86 \pm 0.08 \%$. The results of the three-blend weaning food formulations showed that the protein was highest in sample $\mathrm{c}$ of M60\%: P10\%: S30\% with mean value of 15.86.\% and the met the Codex Alimentarius Commission Guidelines formulated supplementary foods for older infants and young children. The crude fibre range from $0.11 \pm 0.01$ to $0.22 \pm 0.01 \%$, fat $4.82 \pm 0.03$ to $5.25 \pm 0.01 \%$, moisture content range from $6.49 \pm 0.03 \%$ to $7.03 \pm 0.022 \%$. The carbohydrate ranged from $72.26 \pm 0.02 .09 \%$ to $83.42 \pm 0.09 \%$. The mineral content was seen to be higher than the control sample as a result of fortification with plantain and soybean. The formulated foods were nutritionally sound since they could provide reasonable percentage of the recommended daily allowance for protein, carbohydrate, and some micro/macronutrient. Equally, the porridges made from the composites were accepted slightly by the judges, the results of sensory evaluation of complementary food formulations rated more than average for all sensory attributes. The study shows that composite blends are nutritiously adequate for the preparation of weaning foods for infants.

\section{Introduction}

The food suitable for weaning vary from place to place depending on availability, cost, culture, food preference, palatability, provide a sense of society, energy nutrition and so on. A meal is usually made from sectoral foods, each food supplies some energy and different nutrients Adoption of recommended breastfeeding and complementary feeding practices and access to the appropriate quality and quantity of foods are essential components of optimal nutrition for infants and young children (Lutter and Rivera, 2003).

Complementary food is any food other than breast milk given in the complementary feeding period. Complementary foods can be prepared specially for infant or can be the same foods available for family members, modified in order to meet the eating skills and needs of the infant (Cristina et al., 2004). A 
proper complementary feeding consists of foods that are rich in energy and in micronutrients (especially iron, zinc, calcium, vitamin $\mathrm{A}$, vitamin $\mathrm{C}$ and folates), free of contamination (pathogens, toxins or harmful chemicals) without much salt or spices, easy to eat and easily accepted by infants, in an appropriate amount, easy to prepare from family foods, and at a cost that is acceptable by most families (WHO, 2000). As breast feeding continues after six month, it is time to introduce complementary foods, although exclusive breast feeding provides the best start after six month and as long as breast feeding continues, the child needs more vitamins, minerals, protein and carbohydrates than are generally available from breast milk alone. Protein Energy Malnutrition (PEM) and micronutrient deficiencies among infants and young children are the most prevalent nutritional problem in Nigeria (FGN/UNICEF, 1994). PEM is very high with $43.1 \%$ and $22.3 \%$ of under-fives moderately and severely malnourished, respectively.

Vitamin A deficiency in children (under-fives) is higher than $16 \%$ in some regions of the country, while anaemia rates are as high as $50 \%$ (FGN/UNICEF, 1994). The high cost of fortified nutritious proprietary complementary foods is always beyond the reach of most Nigerian families hence many depend on inadequately processed traditional foods consisting mainly of unsupplemented cereal porridges made from maize, sorghum and millet (Nnam, 2002).

There is need to modify and integrate cheap, nutritious and locally available food crops into the traditional complementary food to meet the nutrient and energy needs of infants. Maize grain is used to prepare "Ogi" a traditional complementary food in Nigeria. The grain is low in total protein $(10.65 \%)$ and is limiting in lysine and typtophan (FAO, 1992). Soybean protein, however, is richin lysine and could form a good protein complement to maize. Plantain has promising nutrient potentials and could contribute significant quantities of carotene $(475 \mathrm{pg} / 100 \mathrm{~g})$ in the diet (FAO, 1990).

Maize (Zea mays) is a cereal crops that is grown widely throughout the world in a range environment. Maize is produced more than any other grain annually. The grains are rich in vitamin $\mathrm{A}, \mathrm{C}$, and $\mathrm{E}$, carbohydrate and essential minerals. Raw yellow sweet maize kernels are composed of $76 \%$ water, $19 \%$ carbohydrates, $3 \%$ protein, and $1 \%$ fat. In a 100-gram serving, maize kernels provides 86 calories and are a good source (10-19\% of the daily value) of the B vitamins, thiamin, niacin, pantothenic acid (B5) and folate. In moderate amounts, they also supply dietary fiber and the essential minerals, magnesium and phosphorus whereas other nutrients are in low amounts (Linda, 2013). They are also rich in dietary fibre and calories which are a good source of energy. The white and yellow varieties are preferred by most people depending on region (Afoakwa et al., 2007).

Plantains (Musa paradisiacal) are staple food in tropical regions of the world, ranking as the tenth most important staple food in the world. An average plantain has about 220 calories and is a good source of potassium and dietary fiber. In Nigeria, it is eaten boiled, fried or roasted (Turnbull, 2004). Plantains are also dried and ground into flour "banana meal" forms an important foodstuff with the following constituents; water, $10.62 \%$; proteins, $3.55 \%$; fat, $1.15 \%$; carbohydrates, 81.67\%; and ash, 3.01\%.In southern India, dried plantain powder is mixed with a little bit of fennel seed powder and boiled in milk or water to make baby food to feed babies until they are one year old (Randy, 2007).

Plantain flour is the product of dried and pulverized plantain slices. When processed 
into flour, it is used traditionally for preparation of gruel which is made by mixing the flour with appropriate quantities of boiling water to form thick paste 'Amala' in Nigeria and the flour is however gradually finding application in weaning food formulation and composite flour preparation (Olaoye et al.,2006).

Soyabean is a legume widely grown for its edible bean which has numerous uses. Soybean is becoming popular, it contains $40 \%$ food quantity protein, $20 \%$ fat, $23 \%$ of carbohydrate and reasonable amount of minerals vitamins and is an excellent healthy food. Be a complete protein, it can be useful to fortified food that has limiting amino acid (Purcel et al., 2000). This study was aimed at formulating complementary foods from composite flour from sprouted maize grain, plantain, soybean flour at different substitution levels as well as to evaluate the nutrient and sensory properties of the food blends.

\section{Materials and Methods}

The cereals maize (Zea mays) soyabean (Glycine max) and plantain (Musa paradisiaca) used for this work were purchased from Sayedero market in Ilaro, Ogun state. All the grains and legumes samples were manually cleaned by removing manually the bad ones.

\section{Sample Preparation}

The raw maize was steeped in distilled water in a ratio of 1:3 (w/v) (grain to water) and allowed to ferment in a bell jar at $28 \pm 2^{\circ} \mathrm{C}$ for $24 \mathrm{hrs}$ to produce the traditional maize complementary food. The grains were separated from the steeping water by decanting, grains were spread on wetjute bags and covered with moistened muslin cloth to sprout for $48 \mathrm{hrs}$ at an average room temperature of $28^{\circ} \mathrm{C}$. The grains were washed twice daily with deionized water to avoid the growth of mold. The vegetative parts were carefully removed after sprouting. The sprouted grains was oven dried at $60^{\circ} \mathrm{C}$ for 6 hours, milled and sieved to get flours of fine texture. The flours were separately packaged in a moisture free container and stored until use (control sample \% maize flour) (Nnam and Baiyeri, 2008).

Soyabean was cleaned by sorting, steeped for $12 \mathrm{hrs}$, washed with distilled water, boiled for $2 \mathrm{hrs}$ and oven dried at $60^{\circ} \mathrm{C}$ for 12 hours (Anigo et al., 2010). Plantain was soaked and cleaned by sundried a little time and sliced into small size, then freeze dry in a vacuum oven. The dried samples of maize, plantain and soybean were separately milled into fine flour by passing it through an attrition mills then stored in airtight containers at room temperature until used.

\section{Formulated complementary foods}

Each formulated blend milled was mixed thoroughly in mistral homogenizer into smooth homogenous powder and then stored in airtight containers at room temperature Composites were formulated from the processed foods in ratios of $100 \%$ maize, 65:15:20, 60:10:30, and 70:15:15 (protein basis) maize, plantain soybean respectively. Altogether, four composite flours were formulated as follows;

Sample A: Complementary food (control) sample $100 \%$ maize

Sample B: Complementary food (65\%maize, $15 \%$ plantain and $20 \%$ soybean)

Sample C: Complementary food (60\%maize, $10 \%$ plantain and $30 \%$ soybean)

Sample D: Complementary food (70\%maize, $15 \%$ plantain and $15 \%$ soybean) 


\section{Proximate Composition}

The proximate composition of the complementary foods was determined using standard AOAC methods. Moisture content of the four samples was determined by air oven method (Gallenkamp, Model OV - 440, England) at $105^{\circ} \mathrm{C}$.

The crude protein of the samples was determined using micro-Kjeldahl method, crude lipid was determined by Soxhlet extraction method while the ash content was determined by weighing $5 \mathrm{~g}$ of sample in triplicate and heated in a muffle furnace at $550^{\circ} \mathrm{C}$ for $4 \mathrm{hrs}$. Crude fiber was measured by digestion with $1.25 \%$ sulphuric acid followed $1.25 \%$ of sodium hydroxide. The carbohydrate content was obtained by difference.

\section{Mineral analysis}

Mineral element, $(\mathrm{Mg}, \mathrm{P}, \quad$ and $\mathrm{Zn})$ concentrations were determined using Atomic Absorption Spectrophotometer (Hitachi, model 180-80). Phosphorus was determined spectrophotometrically by the vanadomolybdate method (AOAC, 1990).

\section{Vitamin Analysis}

\section{Vitamin A ( $\beta$-carotene) Determination}

Vitamin A was determined through ultraviolet absorption measurement at $328 \mathrm{~nm}$ after extraction with chloroform. Calibration curve of vitamin A acetate was made and sample vitamin A concentration estimated as microgram $(\mu \mathrm{g})$ of vitamin A acetate.

\section{Vitamin C (Ascorbic Acid) Determination}

Ascorbic acid in the sample was determined by titrating its aqueous extract with solution of 2, 6 dichlorophenol-indophenol dye to a faint pink end point.

\section{Preparation of Porridges}

Porridges were prepared from the composites flours and maize traditional complementary food. One hundred grams of each of the flours were mixed with $600 \mathrm{ml}$ of deionized water. The slurry was heated in a thermostatically controlled water bath at $75^{\circ} \mathrm{C}$. It was allowed to boil for 10 minutes. Two grams of white sugar were added and the gruel was allowed to cool at room temperature to $40^{\circ} \mathrm{C}$ (serving temperature). The samples were kept separately in Thermos flasks to maintain the serving temperature of $40^{\circ} \mathrm{C}$ (Nnam and Baiyeri, 2008). Author 3Title

Sensory evaluation of the ready-to-eat formulated complementary foods was carried out on the taste, appearance, aroma, texture, colour and overall acceptability by a 14 semitrained adult panelists which includes mothers with children age 6 to 24 months and students of federal polytechnic using a 9-piont hedonic scale (Williams, 1982) which range between 1(dislike extremely) and 9 (like extremely).

\section{Statistical Analysis}

Data were reported as Mean \pm SD. Statistical significance was established using One-Way Analysis of Variance (ANOVA) at 5\% level of probability and differences between means were compared using Duncan Multiple range test.

\section{Results and Discussion}

Complementary foods are foods that are readily consumed and digested by young child and that provide addition nutrition to meet all the growing child's needs.

Although exclusive breastfeeding provides the best start, after six months as long as breastfeeding continues WHO/UNICEF (1998). 


\section{Proximate composition}

The result of nutrient composition of maize, plantain with soybean blend is shown in Table 1. The crude protein of the blends varies from $10.64 \pm 0.05 \%$ to $15.86 \pm 0.08 \%$. Sample C had the highest $\%$ and shows significant difference $(\mathrm{P}<0.05)$ while sample $\mathrm{A}$ the control had the lowest value. This shows that inclusion of soybean and plantain flour increases the protein content of the weaning food. Thus, the various blends could provide adequate nutrition as such would not predispose the test child to protein-energy malnutrition if the blends are solely used to wean a child.

The protein levels of the other composites were similar to those of maize based multimixes for use as weaning food in Nigeria (Ketiku and Olusanya, 1986). Sample C meets the Codex Alimentarius Commission Guidelines (15.00\%). The low protein level of sample A \% maize (control) was due to lack of fortification. The crude fibre of the blends varies form $0.11 \pm 0.01 \%$ to $0.22 \pm 0.01 \%$. There was no significant differences $(\mathrm{P}<0.05)$ among the samples but sample D has the highest crude fibre while sample A has the lowest crude fibre, Fibre increases as the inclusion of the soyabean and plantain flour increases. Crude fat blends varies from $4.82 \pm 0.03 \%$ to $5.25 \pm 0.01 \%$ while there was no significant difference $(\mathrm{P}<0.05)$. Crude fat increases as the inclusion of the fortified samples.

The ash content ranges from $1.00 \pm 0.00 \%$ to $3.05 \pm 0.08 \%$, ash content shows significant difference $(\mathrm{P}<0.05)$ while sample $\mathrm{C}$ had the highest value $3.05 \%$. Ash is a measure of the mineral. Ash is a non-organic compound reflecting the mineral content of food. Nutritionally, ash aids in the metabolism of other organic compounds such as carbohydrate and fat (Sowoola et al., 2002).
The percentage ash, which is an indicator of the mineral content of the product, increased with an increase in the percentage of soyabean and plantain flour in all the developed recipes of weaning food. The carbohydrates varies from $72.26 \pm 5.01 \%$ to $83.42 \pm 0.09 \%$. Sample A shows significant difference $(\mathrm{P}<0.05)$ having the highest carbohydrate of $83.42 \%$ and sample $\mathrm{C}$ has the lowest value of $72.26 \%$. The moisture content of the samples ranges from $6.49 \pm 0.02 \%$ to $7.03 \pm 0.02 \%$. Sample C shows significant difference $(\mathrm{P}<0.05)$ among the samples. Low moisture content of the complementary blends may confer the food shelf stable. Although the moisture content of all the samples were higher than similar report of (Bassey, 2013) who formulated weaning food from cooking banana supplemented with cowpea and peanut.

\section{Mineral composition}

The result of mineral analysis on weaning food prepared from maize, plantain with soybeans blend as shown in Table 2.The complementary food had $108.65 \pm 0.04$ to $120.60 \pm 0.03 \mathrm{mg} / 100$ of phosphorus $22.32 \pm 0.05$ to $34.74 \pm 0.03 \mathrm{mg} / 100$ magnesium, $0.81 \pm 0.07$ to $3.54 \pm 0.04 \mathrm{mg} / 100$ zinc, $0.17 \pm 0.07$ to $1.18 \pm 0.01 \mathrm{mg} / 100$ vitamin $\mathrm{A}$ and $1.61 \pm 0.07$ to $7.43 \pm 0.04 \mathrm{mg} / 100$ Vitamin C.

Mineral element concentrations showed that Sample D recorded significantly difference(p $<0.05$ ) higher with comparable values for some of the mineral elements especially Phosphorus, magnesium, and zinc. This shows that addition of soybeans and plantain flour did significantly increase the mineral, so as the level of substitution increase with soyabean and plantain level of minerals increase in the formulated sample proportions, The result also indicates that vitamin $\mathrm{A}$ and $\mathrm{C}$ contents were significantly $(p<0.05)$ higher in sample D while significantly $(p<0.05)$ lower values were observed in sample A respectively. 
Table.1 Proximate composition of complementary food from maize plantain and soy bean blend

\begin{tabular}{|c|c|c|c|c|c|c|}
\hline Sample & $\begin{array}{c}\text { Crude } \\
\text { Protein }\end{array}$ & $\begin{array}{c}\text { Crude } \\
\text { Fibre }\end{array}$ & Crude fat & Ash & Moisture & Carbohydrate \\
\hline A & $10.64 \pm 0.05$ & $0.11 \pm 0.01$ & $4.82 \pm 0.03$ & $1.00 \pm 0.00$ & $6.84 \pm 0.03$ & $84.42 \pm 0.09$ \\
\hline B & $13.61 \pm 0.01$ & $0.13 \pm 0.02$ & $4.93 \pm 0.02$ & $2.20 \pm 1.03$ & $6.49 \pm 0.02$ & $79.21 \pm 0.02$ \\
\hline C & $15.86 \pm 0.08$ & $0.21 \pm 0.02$ & $5.11 \pm 0.01$ & $3.05 \pm 0.01$ & $6.90 \pm 0.07$ & $72.26 \pm 5.01$ \\
\hline D & $12.95 \pm 0.07$ & $0.22 \pm 0.01$ & $5.25 \pm 0.01$ & $2.05 \pm 0.07$ & $7.03 \pm 0.02$ & $79.54 \pm 0.06$ \\
\hline
\end{tabular}

Values with the same letter in the same column are not significantly different

Sample A: Complementary food (control) sample $100 \%$ maize

Sample B: Complementary food (65\% maize, $15 \%$ plantain and $20 \%$ soybeans)

Sample C: Complementary food (60\% maize, $10 \%$ plantain and 30\% soybean)

Sample D: Complementary food (70\% maize, $15 \%$ plantain and $15 \%$ soybean)

Table.2 Mineral composition of complementary food from maize plantain and soybean blend

\begin{tabular}{|c|c|c|c|c|c|}
\hline Sample & Phosphorus & Magnesium & Zinc & Vitamin A & Vitamin C \\
\hline A & $108.65 \pm 0.04$ & $22.32 \pm 0.05$ & $0.81 \pm 0.07$ & $0.17 \pm 0.07$ & $1.61 \pm 0.07$ \\
\hline B & $112.90 \pm 0.04$ & $26.65 \pm 0.04$ & $1.95 \pm 0.04$ & $1.18 \pm 0.68$ & $3.71 \pm 0.04$ \\
\hline C & $117.25 \pm 0.08$ & $30.10 \pm 0.02$ & $2.49 \pm 0.02$ & $1.13 \pm 0.04$ & $5.46 \pm 0.03$ \\
\hline D & $120.60 \pm 0.03$ & $34.74 \pm 0.03$ & $3.54 \pm 0.04$ & $1.18 \pm 0.01$ & $7.43 \pm 0.047$ \\
\hline
\end{tabular}

Values with the same letter in the same column are not significantly different

Table.3 Sensory evaluation of complementary food from maize plantain and soy bean blend

\begin{tabular}{|c|c|c|c|c|c|}
\hline Sample & Colour & Texture & Taste & Aroma & $\begin{array}{c}\text { Overall } \\
\text { acceptability }\end{array}$ \\
\hline A & $5.50 \pm 0.05$ & $5.00 \pm 0.05$ & $4.40 \pm 0.05$ & $4.60 \pm 0.08$ & $5.70 \pm 0.07$ \\
\hline B & $5.50 \pm 0.05$ & $5.40 \pm 0.08$ & $4.80 \pm 0.04$ & $5.00 \pm 0.07$ & $5.70 \pm 0.05$ \\
\hline C & $5.70 \pm 0.07$ & $5.00 \pm 0.07$ & $4.40 \pm 0.05$ & $4.80 \pm 0.08$ & $5.60 \pm 0.08$ \\
\hline D & $6.50 \pm 0.08$ & $5.00 \pm 0.07$ & $5.00 \pm 0.08$ & $5.10 \pm 0.07$ & $6.60 \pm 0.07$ \\
\hline
\end{tabular}

Values with the same letter in the same column are not significantly different

The sensory scored with porridges made from maize, plantain with soybeans blend, in the production of complementary food are shown in Table 3. The mean sensory scores of the baby food were different in taste, flavour, colour and overall acceptability. The mean scores increase with increase in the proportion of soybean and plantain fortified samples in all the weaning food samples in terms of all the sensory attributes tested. The colour of the porridges from sample D and sample $\mathrm{C}$ were much appreciated by the mother and sample $\mathrm{B}$ were moderately liked. The texture of the porridge from sample $\mathrm{C}$ more pleasant by the mother. The taste, flavor and overall acceptability ranges between much pleasant and very liked. The porridge from sample D and sample B was most generally accepted among the sample blend. However, sample D had The overall acceptability rating among all the samples

The study shows that composite maize, plantain with soybean blend are nutritiously adequate and safe for consumption for the preparation of complementary food for infant and children with sample $\mathrm{C}$ having the highest protein and minerals. The sensory evaluation 
shows the porridges prepared from sample D was most preferred to other samples Hence, there is improvement in the nutrient quality of the formulated complementary foods with good acceptability comparable to that commonly used $100 \%$ maize' 'Ogi' which can be improve on with the ultimate goal of contributing to the reduction of malnutrition in children in Nigeria.

\section{Acknowledgement}

The Author wish to appreciate Miss Akinwande Adenike for her assistance in the analysis of the nutrient composition.

\section{References}

Afoakwe E O, Sefa-Dedeh S, Slimpson B A, Sakyi Dawson E. and Asomin J (2007). Influence of Spontneous Fermentatio on Some Quality Characteristics of Maizebased Cowpea-fortified Nixtamalizedfoods. AJFAND (on-online) 17 (1).

Anigo K M, Ameh1, D A, Ibrahim $1 \mathrm{~S}$ and Danbauchi S S. (2010). Nutrient composition of complementary food gruels formulated from malted cereals, soybeans and groundnut for use in North-western Nigeria African Journal of Food Science Vol. 4(3) pp. 65-72.

AOAC (1990). Official method of analysis, Association of Official Analytical chemists, Washington, Dc.

Bassey F I, Mcwatters K H, Edem C A and. Iwegbue3 C M A (2013). Formulation and nutritional evaluation of weaning food processed from cooking banana, supplemented with cowpea and peanut. Food Science \& Nutrition 1 (5): 384 391.

Cristina MG. Monte Elsa R J. Giugliani (2004). Recommendations for the complementary feeding of the breastfed child. J. Pediatr. (Rio J.) vol.80 no.5 suppl. Porto Alegre Nov.
http://dx.doi.org/10.1590/S002175572004000700004.

FA0 (1992). Maize in Human Nutrition. Food and Agriculture Organization of the United Nations, Rome. FAO Food and Nutrition Series, 25, 13-30.

FAO/WHO (1994). Codex Alimentarius Standards for Food for Special Dietary Uses (including foods for infants and children) vol. 4. Joint FAO/ WIIO Food Standard Programme. Rome: WHO, Codex Alimentarius Commission, 5265.

FGN/UNICEF (1 994). The Nutritional Status of Women and Children in Nigeria, UNICEF, Lagos, 4-8.

Ketiku, A. O. and Olusanya J O (1986). Nutrient composition of multimixes for use as weaning foods in Nigeria. Food Chemistry, Vol 2, No 1, pp 47-56.

Linda C F., (2013). "Corn," in Andrew F. Smith (ed.), The Oxford Encyclopedia of Food and Drink in America. 2nd ed. Oxford: Oxford University Press, 2013 (pp. 551-558).

Lutter CK, Rivera JA (2003). Nutritional Status of Infants and Young children and characteristics of Their Diets. $J$. Nutr. Vol.133: 2941s-2949s.

Nnam N M and Baiyeri G T. (2008) E.valuation of the nutrient and sensoryproperties of multlmlxes and porridges made from maize, soybean, and plantainfor use as complementary food.Ecology of Food and Nutrition, Vol 47: 64-76, 2.

Olaoye O A, Onilude A A and Oladoye C O (2007). Breadfruit flour in biscuit making: effects on product Quality African Journal of Food Science pp. 020-023, October, 2007

Purcell L C, Salmeron M, Ashlock L (2000)."Chapter 19: Soybean Facts" (PDF). Arkansas Soybean Production Handbook - MP197. Little Rock, AR: University of Arkansas Cooperative 
Extension Service. p. 1. Retrieved 5 September 2016. +6

Randy C P, Angela K K, Jeff D and Scot C N (2007). "Banana and plantain - an overview with emphasis on the Pacific island cultivars" (PDF). Species Profiles for Pacific Island Agroforestry. Traditional Tree Initiative. Retrieved 5 June 2016.

Sowoola OA, Ashaye OA, Akinde BA (2002) Quality Evaluation of Ebiripo cocoyam/soybeans/soy residue blends. $J$ Food Technology Africa Vol7: 1.

Turnbull, P., (2004)."Plantains". South Seas Companion. Retrieved 18 November 2016.
WHO (2000). Complementary feeding: Family foods for breastfed children. Geneva: World Health Organization. WHO/NHD/00.1:

$\mathrm{WHO} / \mathrm{FCH}$ /CAH/00.6; 2000.

WHO/UNICEF (1998). Complementary feeding of young children in developing countries: a review of current scientific knowledge. Geneva: World Health Organization, WHO/NUT/98.1,1998.

Williams AA (1982). Scoring Methods in the Scoring Analysis of Foods and Beverage at Long Ashton Research Station. Food Technol. Vol 17:163-175.

\section{How to cite this article:}

Noah Abimbola Aduke. 2017. Nutrient Composition and Sensory Evaluation of Complementary Food Made From Maize, Plantain Soybean Blends. Int.J.Curr.Microbiol.App.Sci. 6(12): 5421-5428. doi: https://doi.org/10.20546/ijcmas.2017.612.507 